\title{
Correction to: Spiritual Care of Inpatients Focusing on Outcomes and the Role of Chaplaincy Services: A Systematic Review
}

\author{
Robert W. Kirchoff ${ }^{1}$ (D) - Beba Tata ${ }^{1}$ - Jack McHugh ${ }^{1}$ - Thomas Kingsley ${ }^{1}$. \\ M. Caroline Burton ${ }^{1} \cdot$ Dennis Manning ${ }^{1} \cdot$ Maria Lapid $^{1} \cdot$ Rahul Chaudhary $^{1}$
}

Published online: 5 April 2021

(C) Springer Science+Business Media, LLC, part of Springer Nature 2021

\section{Correction to: Journal of Religion and Health (2021) 60:1406-1422 https://doi.org/10.1007/s10943-021-01191-z}

In the original publication of this article, the reference "Johnson et al., 2014" is erroneously cited as "Johson et al. 2014" in Table 3 and "Johnson and colleagues (2007)" in text which were not mentioned elsewhere in the manuscript. This reference can be completely removed and replaced with Johnson et al. (2014) as given below:

"Johnson, M. E., Piderman, K. M., Sloan, J. A., Huschka, M., Atherton, P. J., Hanson, J. M.,.. Frost, M. H. (2007). Measuring spiritual quality of life in patients with cancer. Journal of Supportive Oncology, 5(9), 437-442."

Should be changed to:

Johnson, J. R., Engelberg, R. A., Nielsen, E. L., Kross, E. K., Smith, N. L., Hanada, J. C., Doll O'Mahoney, S. K., \& Curtis, J. R. (2014). The association of spiritual care providers' activities with family members' satisfaction with care after a death in the ICU*. Critical Care Medicine, 42(9), 1991-2000. https://doi.org/10. 1097/CCM.0000000000000412.

Publisher's Note Springer Nature remains neutral with regard to jurisdictional claims in published maps and institutional affiliations.

The original article can be found online at https://doi.org/10.1007/s10943-021-01191-z.

Robert W. Kirchoff

kirchoff.robert@mayo.edu

$1 \quad$ Mayo Clinic, 200 1st St SW, Rochester, MN 55902, USA 